\title{
Attributes Function Study on Baliem/ Hubula Tribe Wars Costumes
}

\author{
Anggira Paramita Putri ${ }^{1, *}$ Nuning Yanti Damayanti ${ }^{2}$ \\ ${ }^{1}$ FSRD- Bandung Institute Of Technology \\ ${ }^{2}$ FSRD-Bandung Institute Of Technology \\ *Corresponding author.Email: giesanjaya88@gmail.com
}

\begin{abstract}
Art is one of the human culture products and elements that indicates a nation character and personality. Indonesia has various cultures since consisting of many tribes and ethnicities. Papua's tradition and culture in Indonesia is not widely known, especially the mountainous area of Central Papua. The Hubula tribe creates artistic products as a means to express beauty, life experiences and the meaning of life. Tangible as well as intangible cultural heritages,such as dance, clothing, jewelry, weapons, traditional ceremonies. This paper is an initial research on the study of the function of the artibut of war costumes, focusing on the jewelry and weapons of war worn by the Baliem Valley Hubula tribe. The method used is descriptive qualitative through the stages of field surveys, data collection, data recording, literature study, studies in the field of Fine Arts and analysis of the ethnographic approach. The results of the analysis show that the attributes of the war costumes of the Hubula Lembah Baliem community in addition to having aesthetics (beauty) also have a special function. Attributes of war are made from the nature around them and have important life meanings so that their existence is still maintained today. Attributes of war function not only as a complement but become a symbol of the early history of war and can be told from generation to generation. The real evidence of the war attributes still exists and is preserved in the Honai custom of war. Attributes of war costumes are cultural heritage products of art and values contained in the war tradition that war is not to kill each other between tribes or groups, furthermore it is an effort to defend oneself.
\end{abstract}

Keywords: War costumes attributes, Hubula tribe, Baliem jewelry, Papua, Esthetic Function

\section{INTRODUCTION}

Papua Province is located at the most eastern of Indonesia which has the largest area compared to other provinces in Indonesia. The total area of Papua Province is 309.934.4 km2 (after the formation of West Papua). Papua Province is bordered by West Papua Province on the west, Pacific Ocean on the north, Arafuru Sea on the south and Papua New Guinea on the east. In physiography term, northern part of Papua Province is a lowland stretches from Lake Sentani to Sarmi, while southern part is a lowland from Asmat, Timika, to Merauke. In central part of Papua Province, there are Jayawijaya Mountains and Sudirman Mountains (part of Central Mountains). The highest peaks are Karten Pyramid, which is 4,884 meter $(\mathrm{m})$ above sea level (asl), Puncak Jaya is $5,500 \mathrm{~m}$ asl, Trikora Peak is $5,160 \mathrm{~m}$ asl and Yamin Peak is $5,100 \mathrm{~m}$ above sea level. 


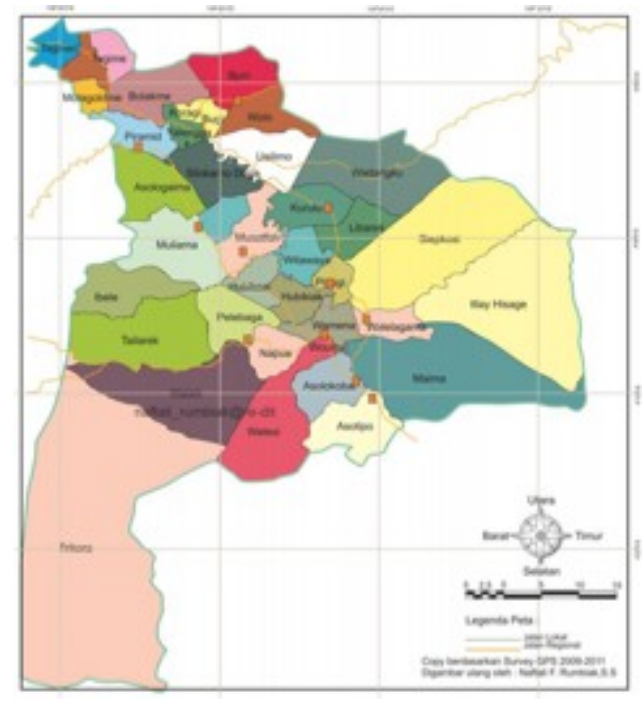

Figure 1 Jayawijaya Districs Map (source: Dinas Kebudayaan and Pariwisata Kabupaten Brawijaya)

There are five (5) major tribes in the Central Mountains Hubula Tribe, Yali Tribe, Hubula Tribe, Lani Tribe, and Ngalik-Siat Tribe. The first human ancestor origin story of one of Papuan tribes, that being passed down along generations, is known as Hubula Tribe who lives in Baliem Valley. Baliem is name of the largest river in Baliem Valley glorified by Hubula Tribe which in Hubula language means "you cut", in harmony with the geographical environment of Palim River which flows and stretches in the middle of the mainland from west to east and south. The word baliem derrived from the word palim, therefore Palim River changed to Baliem River since the 1950s when the missionaries and the Dutch government expanded in Wamena [14]. The natives of the Hubula Tribe themselves do not understand the meaning of the word and do not know the origin that gave their Tribe name.

The Hubula Tribe is a name for a social group based on war alliances and confederations, such as the kurima region, asolokoobal, ohena, wio, mukoko, wita-waya and so on [1]. The name Hubula as the name of the indigenous tribes in the Baliem Valley was officially stipulated at the Papuan People's Congress in 2000 and specifically since the formation of the Papuan version of the Papuan Customary Council in 2001
[14]. In 2002, the community was grouped into a separate tribe with the name of the tribe ; Hubula, who studied the Baliem Valley. The people in the western part of the Valley are called the Lani Tribe, in the north they are called the Walak Tribe, in the eastern part behind the Valley are called the Yali Tribe and in the south are called the Nduga Tribe [1].

Culture is a manifestation of ethnic identity. Ethnic identity is one aspect of developing identity and preserving the life values of indigenous peoples which aim to create a sense of unity. Art is part of culture since art was born from existing cultures and formed the character of that culture. The arts owned by the ethnic groups in Central Mountains Region are a method to express a sense of beauty, life experience and life meaning of human soul. Hubula Tribe and other tribes who inhabit the Central Mountains region in general still adhere to customs, but over time the values of customs, spiritual values and beliefs have decreased.

The natural conditions that underlie human life are marked by several events that have a very large influence on human life. Humans have an advantage over all other types of animals in terms of having a developed mind. The development of the human mind which is reflected in the results of the culture created is strongly influenced by the surrounding natural environment [10].

Ethnographic sources describe the existence of several tribes that still have prehistoric elements in socio-economic life and belief aspects [13]. However, since modernization, Honai laws relating to warfare have been rare and even obsolete. The Hubula Tribe made changes and made war a tourism commodity such as the Baliem Valley Festival. This festival is one way to maintain Papuan local wisdom. They still maintain this tradition and teach it from generation to generation. The goal is not to fight and kill each other with other tribes or groups, but they want to pass on the values contained in the tradition of war. One of them is the obligation to protect the village or village from enemy attacks. This is a form of their love for the village or tribe wher they were born. The term jewelry in the Indonesian dictionary is something that is used to decorate oneself. Therefore, the Hubula tribe also has jewelry and war equipment not only to decorate themselves but to protect themselves and have their own values in their customs and culture. Like the accessories and war attributes that the Hubula Tribe has made of natural materials that are around them. The objects 
used to decorate the body contain meanings in accordance with cultural traditions that are still maintained today. This paper is an initial research on the meaning of war costumes in the Hubula Tribe, focusing on the jewelry and weapons of war worn by the Hubula Valley Baliem tribe. The purpose of this research is to understand and describe the tangible and intangible cultural heritage, focusing on the attributes of war costumes and ornaments of the Hubula Tribe. The benefits of the research results can trace the traces of the civilization of the ancestral life of the Hubula Tribe which produces the function of cultural products in the form of attributes of war costumes and jewelry.

\section{METHOD}

The method used is through the stages of collecting image and photo data, literature studies, field surveys, studies in the field of Fine Arts and analysis of the ethnographic approach. Data collection is done by using documentation techniques. Documentation technique is done by collecting data in the form of documents related to the object being analyzed. Literature study to collect written information from books, articles, journals as reference material. Survey, by conducting direct observations in the field with data collection formats, both verbal (recording and measuring) and pictorial (photographing and drawing). Interviews and using an ethnographic approach were also conducted selectively with traditional leaders and local cultural services. Studies in the field of Fine Arts by means of image analysis on several photos of attributes of war costumes, weapons and jewelry.

\section{HISTORY OF TRIBAL WAR}

Humans have known war since centuries ago. Initially the rules of war were regulated in rules of conduct, morals and religion. Currently the rules of war are better known as International Humanitarian Law, also called the law of war which later developed into the law of armed conflict [9].War or in Baliem language called as wim/wein, has became a tradition. The tribal wars, that often occur between Hubula Tribe people in Baliem Valley, especially in Central Mountains region, generally have various backgrounds. Conflicts between community groups between one tribe and another might be caused by hereditary grudges due to past events, such as seizure of land (ulayat rights), theft of pigs (customary payment instruments), infidelity and adultery. The war occurrence in people of Central Mountains region is divided into two, namely tribal wars due to the resistance between tribes (different tribes) and civil wars (one tribe). The party who won the war kept the evidence of his victories such as a spear (sage), an arrow (siken), tie (walimo/sion) and other objects taken from the body. The war weapon used as injuring enemy evidence so that the enemy became a victim (died). These objects are used as sacred objects that worshiped and sacred. The evidence ( $a p$ warek or sue warek) would be paraded by the tribe that has succeeded in attacking the opponent by singing a dance (etai), then the evidence is handed over to the tribal chief (wim tugure/menehule). After that, a traditional ceremony is carried out by dancing and singing (etai), then wrapped and then tied everything into one knot and stored in the Honai culture war (honai wein/wim aila). The kept physical evidence is a trigger for a prolonged personal grudge. Conflict theory according to Lewis Coser views social systems as functional. According to Coser, conflict does not always have a negative nature. Conflict can also strengthen the relationship between individuals in a group. Lewis Coser assesses that conflict has a positive function if it can be managed and expressed properly [12].

Based on ministerial regulations 42 of 2009 and 40 of 2009, preservation is an effort to protect the development and use of dynamic culture. The philosophy of preservation is based on the human tendency to preserve cultural values in the past that have significance for future generations. Efforts to preserve a traditional culture are not only the duty of the community that owns the culture but also all stakeholders and the Central Government and local governments's duty to maintain and preserve it. The Papuan Regional Government has made several policies to maintain and preserve Papuan cultural traditions. The policy of the Papuan Regional Government is to protect, maintain, and preserve cultural traditions that potentialy boost Papuan tourism, for example well known traditional arts, such as dances, carving arts, festivals, war culture, and others. One of the events of Baliem Valley Festival which is held as an initiative of the government and local indigenous peoples displays the entire culture of the tribes in Baliem Valley. One of the displays is the reconstruction of the warrior tradition. The war reconstruction depict the reason of cross-tribes or group wars. The war costumes attributes and jewelry in Baliem Valley are quite interesting to discuss as they have been produced and worn since pre-modern times until now. 


\section{RITUALS AND ATRIBUTES OF WAR}

Ritual is a procedure in a ceremony or a sacred act carried out by a group. It is characterized by the existence of various elements and components, namely the time, the place where the ceremony is carried out, the tools in the ceremony and the person who performs the ceremony [7]. Etai hulung dance or dance with a running back and forth movement in the same direction is one of the traditional dance arts that is exhibited by following rhythm of the song being sung. Etai hulung dance is performed during traditional ceremonies and as an entertainment dance. This dance is performed in a limited number of participants, ranging from a dozen to tens of people. This dance is performed in several places, especially during war. The dance is performed while singing aloud. Although the war is going on, this dance can still be enacted in every village (silimo), Honai Culture War building yard, or other open places. This was done before there was an agreement or the joining of 2-4 other villages to carry out war. The purpose of performing etai hulung dance during the war is to raise the fighting spirit when facing the enemy. This dance lasts until the war ends and sue warek inauguration ceremony is held (keeping objects or evidence of symbols of victory). This ceremony is considered a tool of worship and is very sacred.

According to Banoe, folk songs in Indonesia, namely songs from certain regions or certain cultural areas, are usually stated in the poetry or lyrics of the regional (regional) language, both folk songs and newly created songs. Indonesia's homeland is very rich in folk songs. Almost every region has its own song as a picture of the life of the local community in general [3]. Hubula Tribe has an obligatory song, namely okwaik or etai ewetai (as Baliem people call it) which is one of the great songs in Central Mountains. Okwaik song is sung at the beginning and end of every victory war.

Okwaik song is sung by the victorious party after the war ends in order to find out who won the war. If both sides experience the same number of casualties means that the victory of the war is a victory for both parties. If you want to know the number of victims, etai okwaik song would be sung according to the number of victims.

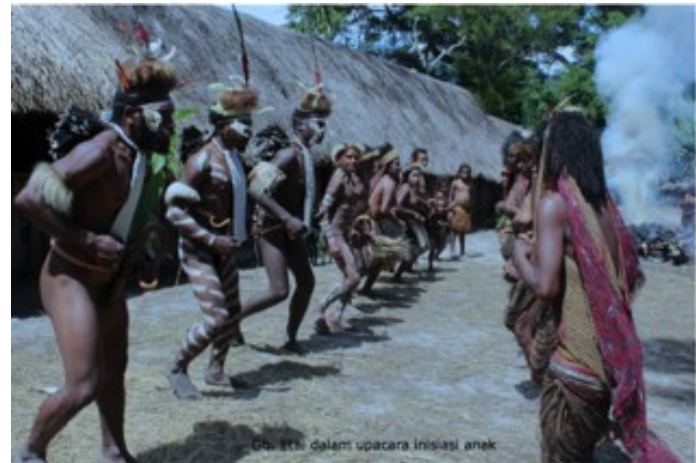

Figure 2 Singing Okwaik Song (source: Department of Culture and Tourism of Brawijaya Regency)

Jewelry is present in the midst of human life as a medium for expressing feelings that are manifested in a visual form whose creation process cannot be separated from environmental influences. It was created as a complement to the aesthetic sense or the satisfaction of the sense of beauty. Besides that, jewelry in various forms is a device that has various meanings that intersect with the interests of certain beliefs and sacred feelings according to what is conventionally applied in the supporting community [5]. All the materials used for jewelry are very simple and easy to obtain from nature such as leaves, flowers, fruit, wood, stones and bones. Jewelry is meant not only jewelry worn by women but also worn by men. Jewelry becomes a unit to complete the attributes of war other than weapons for the Hubula Tribe men. The crown is one of the war attributes of the Hubula Tribe. The crown shows personality identity

The crown is one of the war attributes in Baliem Valley. The crown shows the identity of a man's personality in traditional ceremonies, dances, wars, and everyday life. Silukisi and inumusi, crowns made of cuscus feathers, are war attributes worn by tribal chiefs as well as warlords. A tribal chief, as well as a warlord, moved gallantly slowly towards a fairly wide meadow. Black streaks of charcoal are smeared on the face, an oversized crown is worn on his head. Mr. Yali, as he is usually called, vigilantly watches every movement in the meadow. Made from red parrot feathers called wio, the decoration is combined with home feathers and connected to cuscus feathers (silukisi) and in the middle and top with bird feather decorations called suesi. Silukusi and inumusi are made of cuscus skin where the name sleeps in Baliem called hageik/paik siluki and inun. 


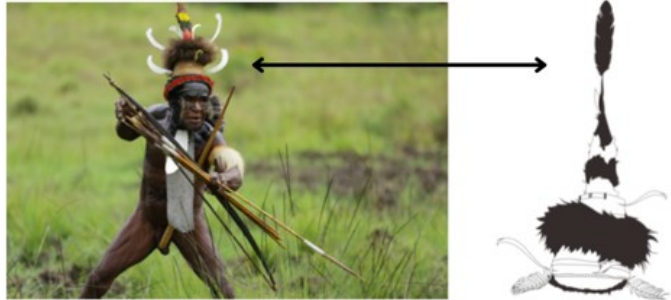

Figure 3 Silukisi and Inumusi worn by Mr. Yali as Tribal Chief (source: Department of Culture and Tourism of Brawijaya Regency)

Kare-kare, a crown made of parrot feathers, used on men heads. Two basic colors of frequently used kare-kare, that have its own meanings based on the beliefs of Hubula Tribe, are red kare-kare made from parrot feathers known as kare werene kare in Baliem language and white kare-kare made parrot feathers known as kare kur/jakik kare in Baliem language. Kare werene kare is used by ap wita group and kare kur/jakik kare used by ap waya group. The basic color division of kare-kare is called ewesula inn Honai culture. The ap waya group is Central Baliem community from Wuka Huby Sub-tribe (along Ue riverbank) to Silokarno Doga Sub-tribe (Watikam Mountain area) on the eastern border of Baliem River, are usually using kare warene kare and not allowed to use kare kur/jakik kare. Meanwhile, people lived in west of Baliem River are usually using kare kur/jakik kare and also not allowed to use kare werene kare. This crown is used in every tradition ceremony,danceand war and usually worn by war soldiers.

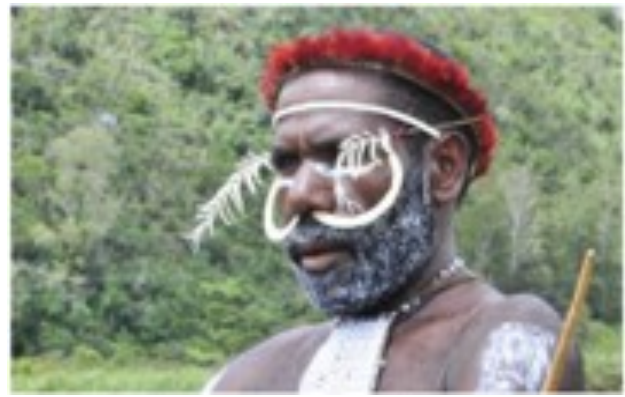

Figure 4 Kare werene worn by ap wita group (source: Department of Culture and Tourism of Brawijaya Regency)

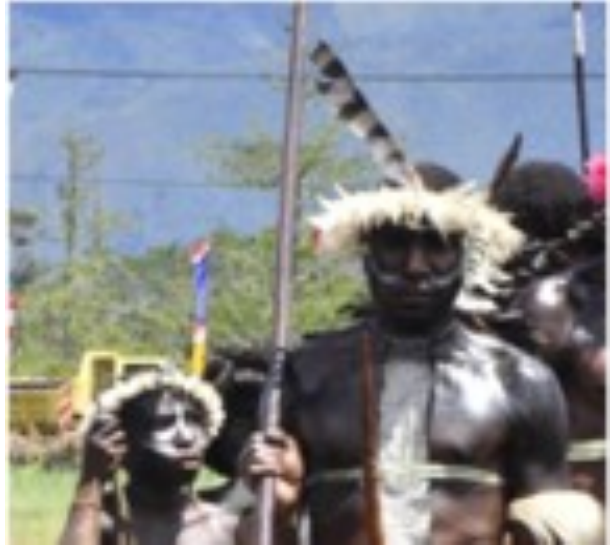

Figure 5 Kare jakik/kur worn by ap waya group (source: Department of Culture and Tourism of Brawijaya Regency

Wam maik or pig fangs are one of the objects used as cultural objects. Wam maik are placed on man's nose as a complementary war attribute. A man in the custom of Hubula Tribe usually makes a hole through the flesh that separates two nostrils. Making holes in the meat bulkhead that limits the two nostrils using a needle or wood that has been made sharp in the form of a nail and then pierced through the meat of the bulkhead, the piece of wood used is called a pawn. The two ends of wam maik are inserted into the nose that has been perforated and placed downward or upward according to the wearer's wishes. Wam maik are a symbol of splendor for a man since shows an attitude of dexterity, courage and is highly respected in the eyes of the community.

Walimo is a traditional tie worn on men chest. Walimo is worn by both men and women, but with the stipulation that men use large-sized accessories, while women use medium or small sizes. It made of rattan wood and woven according to height of the person who wear it. This tie worn is believed to bring magical powers.

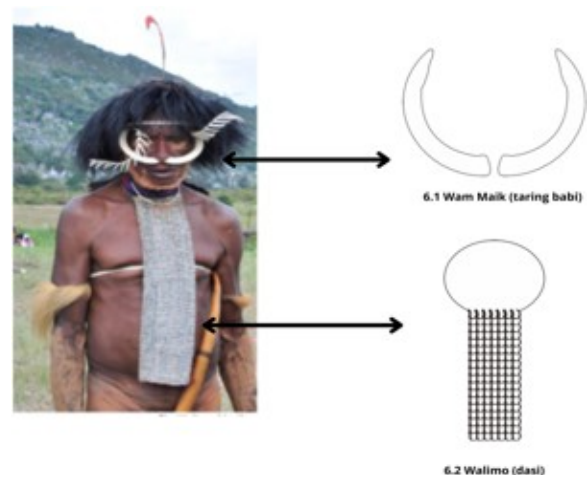

Figure 6.1 Wam Maik (pig fang) 
Figure 6.2 Walimo (tie) (source: Department of Culture and Tourism of Brawijaya Regency)

Muliage is shaped like a long piece of wood measuring $70-90 \mathrm{~cm}$, which is held in the hand. Mulage is made of cassowary feathers (typusi), while the handle is made of rattan or wood. Muliage Used in traditional ceremonies, etai dance, even during a war.

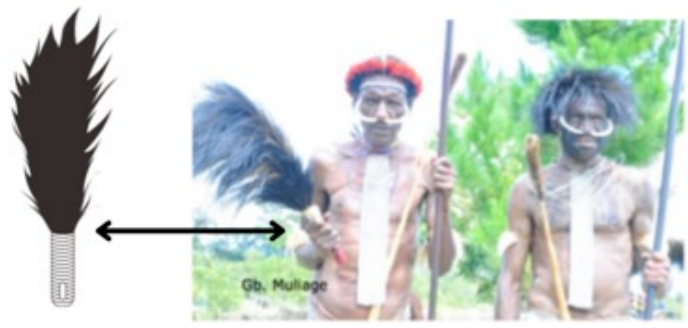

Figure 7 Muliage

(source: Department of Culture and Tourism of Brawijaya Regency)

Melaik or mikak (chest decoration) are accessories for men's chest decoration as a complement to body decoration, including during war. This jewelry hangs around neck and rises to chest. Melaik or mikak is also a symbol of men's greatness crown. Basic ingredients of melaik are large seashells which are split and woven, with cowhide pinned on the front. Melik also symbolizes the number of enemies who have been killed in tribal wars.

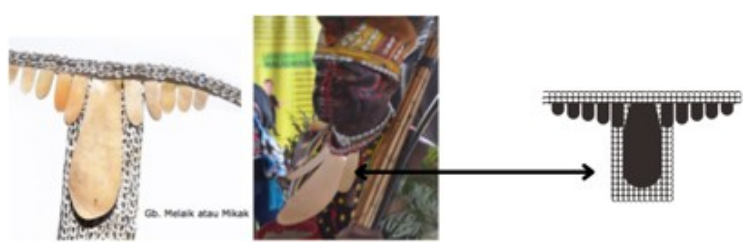

Figure 8. Melaik or Mikak

(source: Department of Culture and Tourism of Brawijaya Regency)

Jekesi is accessories worn by men on left and right arms. Made from dog hair, usually, a dog is cut for consumption and the tail is taken by separating the fur from the tailbone then drying the fur under the sun. After drying, it is sewn using a thread (jolalek). Jeksi is a tool to showing Hubula Tribe man's greatness.

Jamaican su or hulupus is an ornament made of bird feathers that are placed on the back of a man of Hubula Tribe. Made from eagle feathers or jamaik feathers woven on a small noken (su hotik). The meaning of jamaican su or hulupus as tool is to show Hubula Tribe man's greatness.

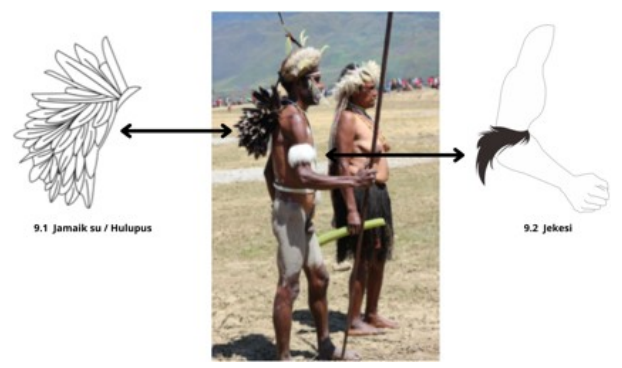

Figure 9.1 Jamaik su or Hulupusu

Figure 9.2 Jekesi (source: Department of Culture and Tourism of Brawijaya Regency)

Halalue is a necklace that is hung around a man's neck. Made from rattan skin, finte, sikipupuk orchid fruit, and yarn (jolalek). This necklace is used as a compliment. Holim or koteka is the name of the traditional clothing of Hubula Tribe. Made from a type of water gourd that is processed in such a way that it becomes a traditional clothing material to cover the genitals of men. The word holim comes from the Baliem language which is generally known as koteka, derived from Me Tribe language in Paniai. There are twi use of holim, namely holim used during the implementation of traditional ceremonies and daily activities is called holim eweholim, and holim used at work is called holim.

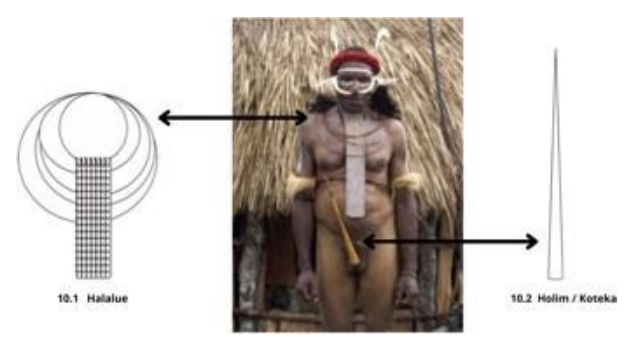

Figure 10.1 Halalue Figure 10.2 Holim / Koteka (source: Department of Culture and Tourism of Brawijaya Regency)

Sawusa, an object that covers the buttocks of men and tied at the waist, is made from japeka leaves. Sawusa is used for everyday use but also can be used as a complement to war.

Weki is a facial dye made from wood charcoal mixed with pork oil and then rubbed on the forehead (testa), left cheek, right cheek, nose, and chest. The smearing is done by using pipireka and siragenka leaves. Some use clay on the eyes, thighs and arms. Weki is a complement to war so that men look dashing and respected. 


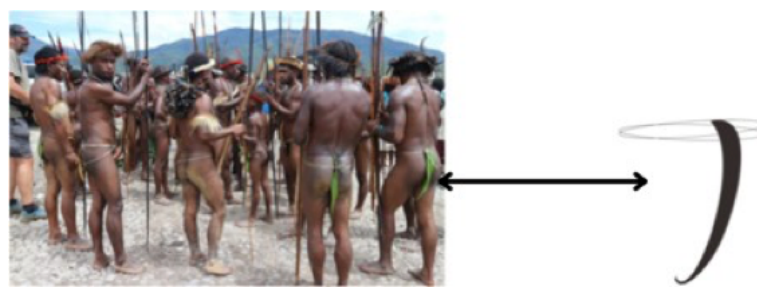

Figure 11 Sawusa

(source: Department of Culture and Tourism of Brawijaya Regency)

Wam amok is a basic ingredient used to decorate the body as a skin protective material and maintain the stability of skin health. The Baliem consider that applying pork fat on the body is a tradition that must be done. Rubbing pork oil on one's body is usually used during traditional ceremonies, dances, long trips, wars and daily activities. The Hubula believe that rubbing pork oil on the body may maintain health, stay young, refresh the body and cure diseases.

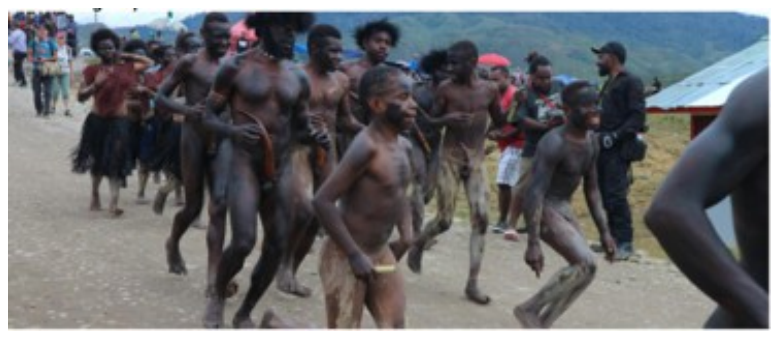

Figure12 Weki and Wam Amok (source: Department of Culture and Tourism of Brawijaya Regency)

Tabel 1. Attributes War Costumes and Jewelry

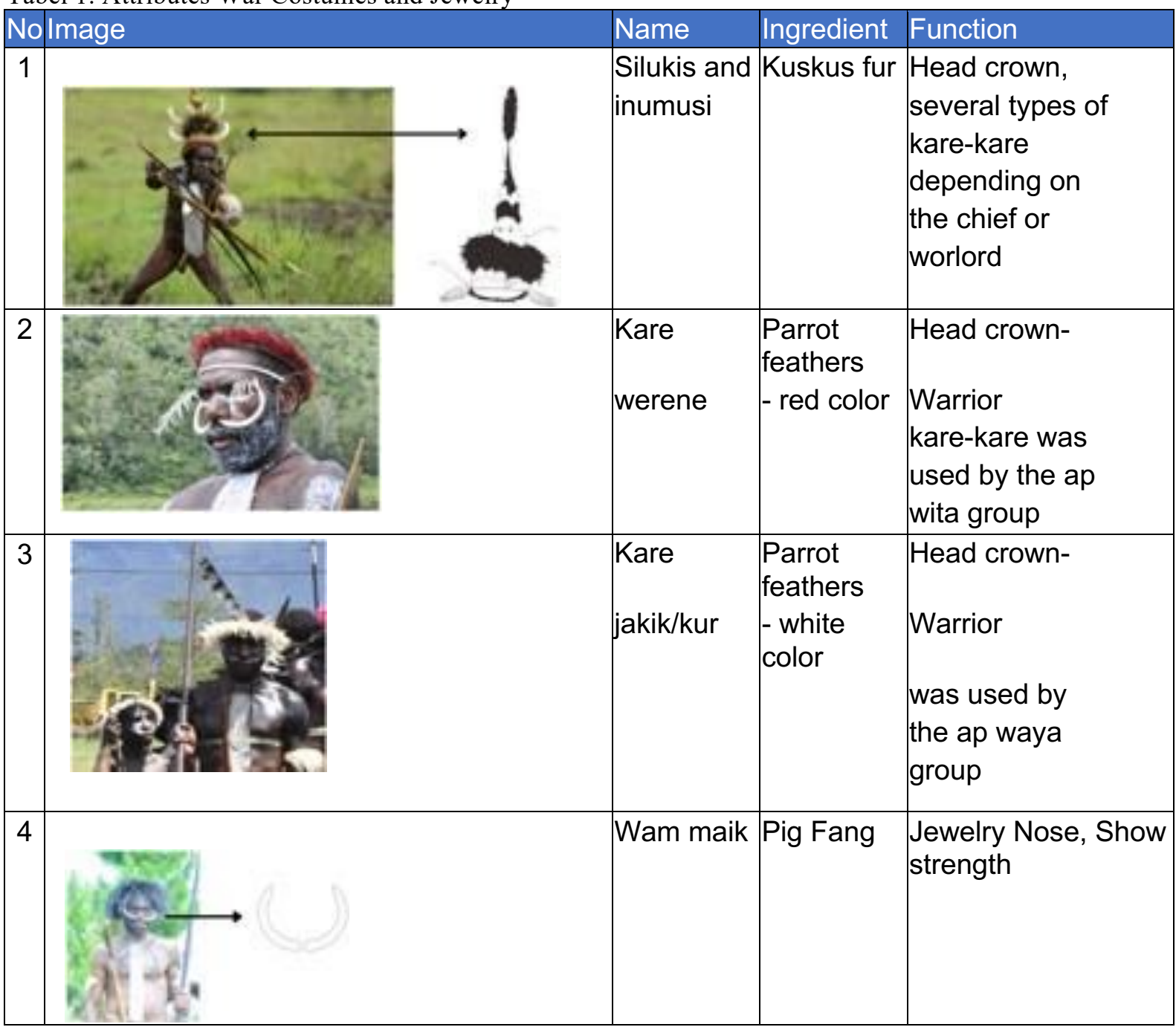




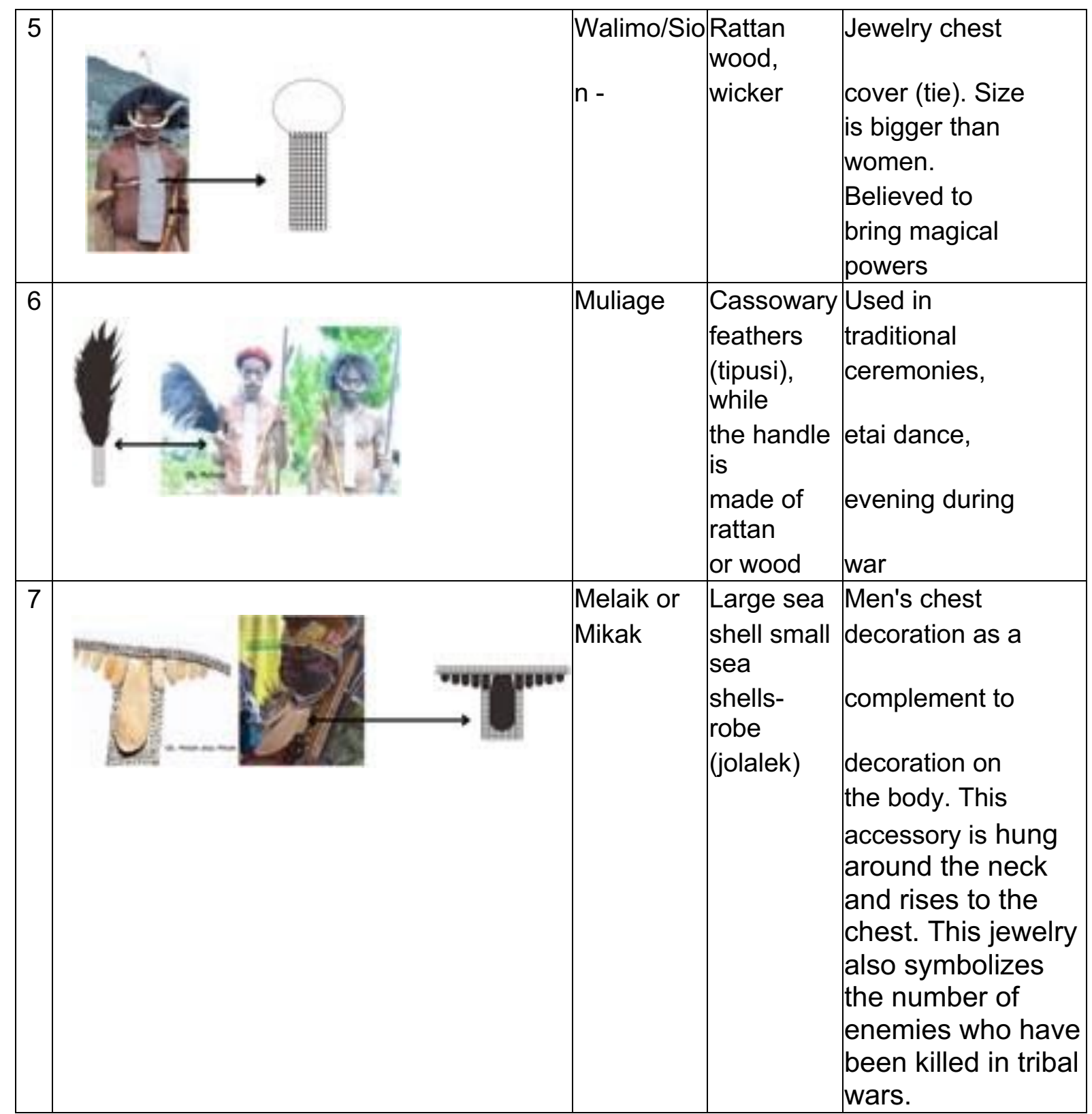

\begin{tabular}{|l|l|l|l|}
\hline 8 & $\begin{array}{l}\text { Jekesi - } \\
\text { sleeve } \\
\text { decoration }\end{array}$ & Dog hair & $\begin{array}{l}\text { Hand } \\
\text { ornaments and } \\
\text { as oversized } \\
\text { jewelry than can } \\
\text { show the } \\
\text { greatness of } \\
\text { men }\end{array}$ \\
\hline
\end{tabular}




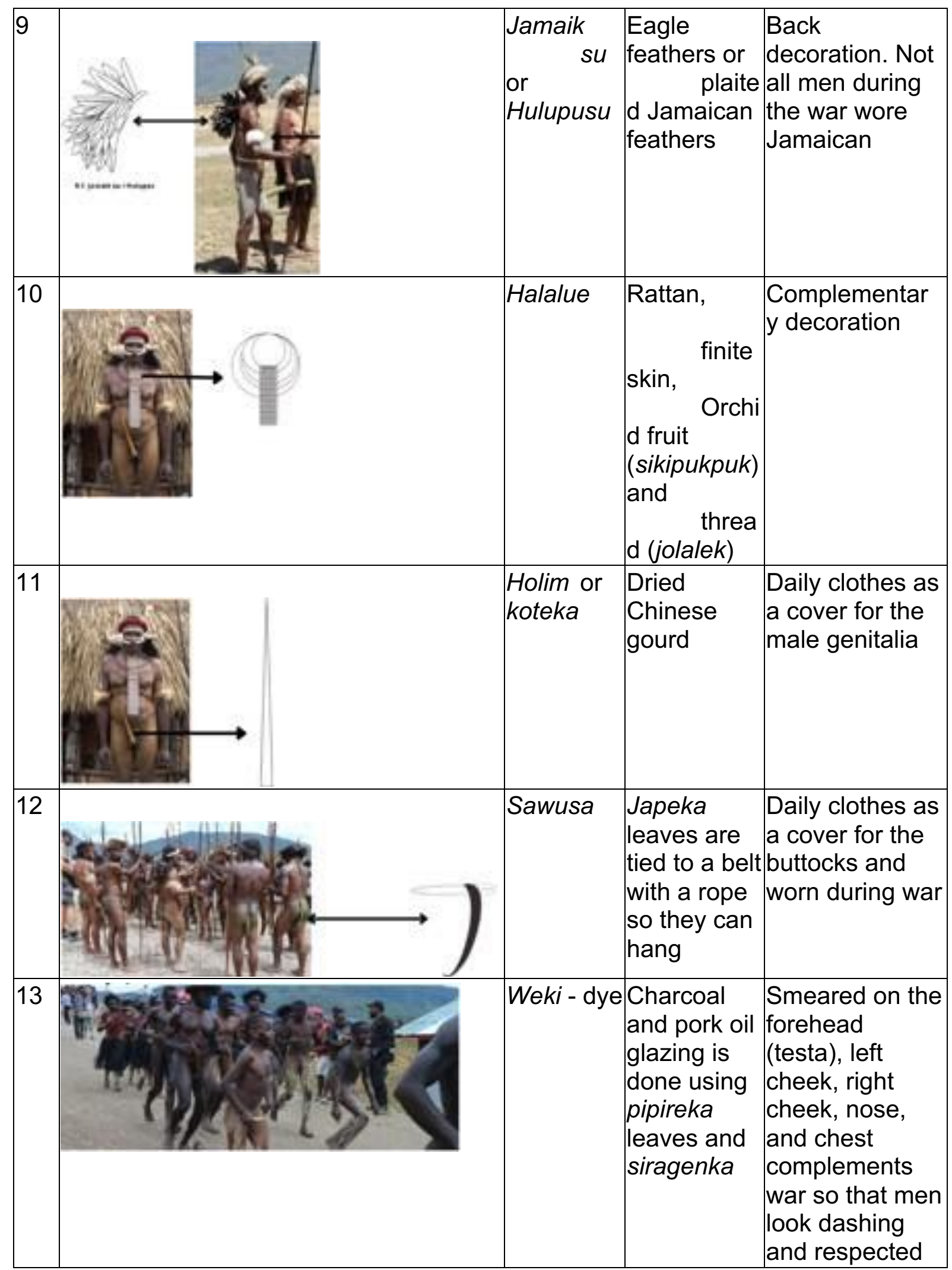




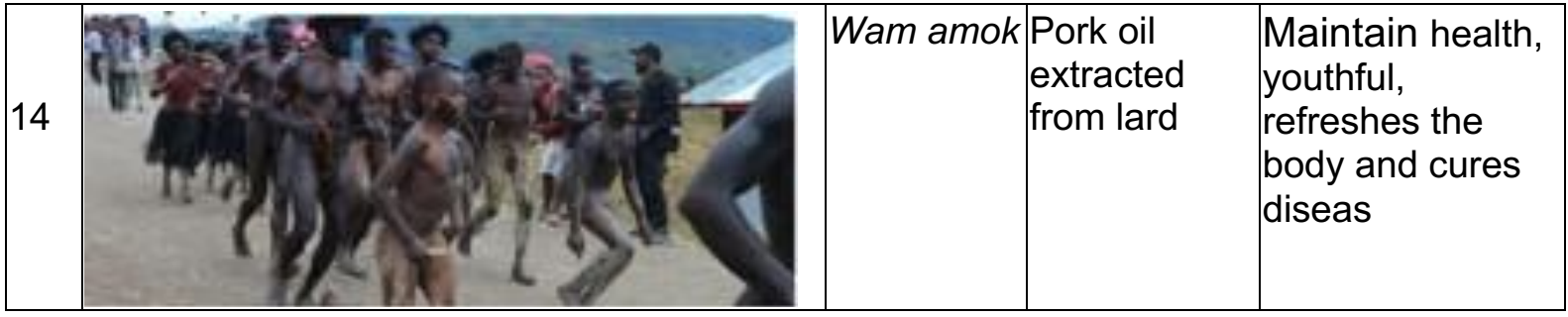

As a complement to jewelry, it is not absolutely necessary for everyone to wear, because jewelry is not a primary need. Jewelry plays an important role in the social life of certain people. Being without reality has no meaning but based on concrete life experiences it has a deep meaning as the Hubula Tribe still maintains and utilizes natural materials for the manufacture of war attributes. All materials used are from the natural environment such as leaves, wood, stone, feathers, and bones. The material used in making the attributes determines the shape so that it functions according to what has been described in the table. Hubula tribe men wear jewelry as an attribute of war is used completely, then a man is considered to have had a perfect appearance. Apart from being a defender of customs, it also reflects the attitude of courage, leadership, skills, and authority to be respected by the community. The attributes of the war costumes also have the meaning of belief and a means of completing the ritual ceremonies that have been believed to this day. So that it not only has a function but has an invaluable cultural value.

\section{TRADITIONAL WEAPONS}

The definition of weapons according to linguists consists of three meanings, namely: First, as a tool used for fighting or fighting such as, for example, kris, rifles and so on. Second, it is a tool used to get something purpose. The third is the sound mark in Arabic script; fatah, kasroh, domah and so on [4]. Moving on from the above understanding what is meant by weapons in this paper are used for war or hunting. Archaeological evidence is almost all over the world, since prehistoric times humans have used various weapons, as well as in Indonesia. At the time of hunting and gathering food, humans recognized and used weapons made of stone, bone and wood. The Baliem Valley Hubula tribe has traditional weapons that are often used for hunting and war. The traditional weapon of Hubula Tribe is made into a tool of war in the form of a wooden spear called sage haliken. There are two types of war spears, namely black Joli sage made of ironwood (joli) and white Lugu sage made of white ironwood (innocent). The average length of the spear is 3 meters (three) to 3.5 meters (three and a half). There are carvings or webbing called sege sigil. The spear works to stab the enemy at close range $\pm 2-3$ meters.

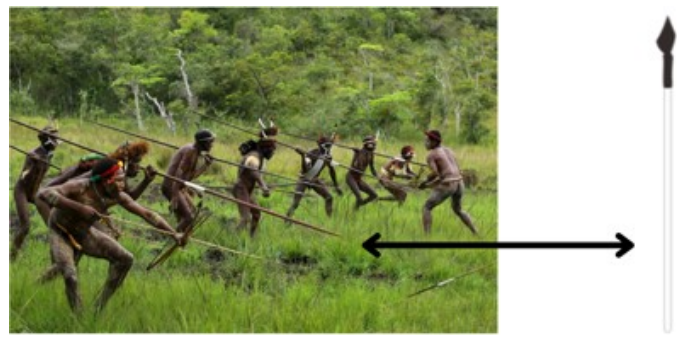

Figure 13. Sage Haliken (source : Indonesiakaya.com- war reconstruction)

$J u b i$, or arrow in Hubula Tribe language, is one of the traditional war weapons. There are three types of arrows, specifically a black arrow named sike ewesike, a white arrow named sike wolokonsike and a white arrow named sike harmaman. The following is an explanation of parts of the whole arrow (Jubi), namely arrows or jubi called sike, arrows called tok eken, bowstrings called sike ikila. The arrows called tok eken consist of wim or wein tok made of bamboo. Tok is made of ironwood, tok aik waganek is an arrow carved with teeth (tooth pattern) and tok pagom tok is a type of arrow with ordinary carvings. The arrow works can glide within a distance of \pm 10 -15 meters. For Hubula Tribe people, especially in Central Mountains, every man is required to have a spear and arrow. Each man will keep the war weapon in the house or stored in groups. Before storing war weapon, Hubula Tribe always used pork oil for its treatment. 


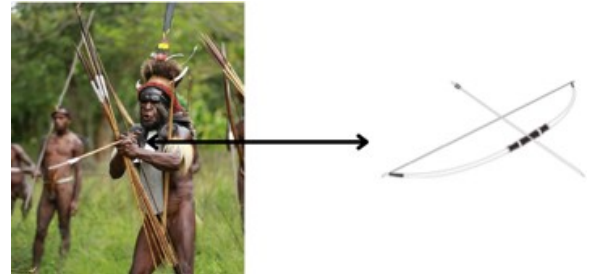

Figure 14. Jubi

(source : Indonesiakaya.com- war reconstruction)

Sticks or can be called totok are one of the tools in the form of a long stick that a man holds while dancing Etai dance and is also used during the battlefield as a weapon to deflect arrows. Made of hite or fite wood, bird feathers and jolalek rope. Totok is one part of the complementary weapon in
Baliem war attributes. These weapons also serve as protection from wild animals attacks in the forest.

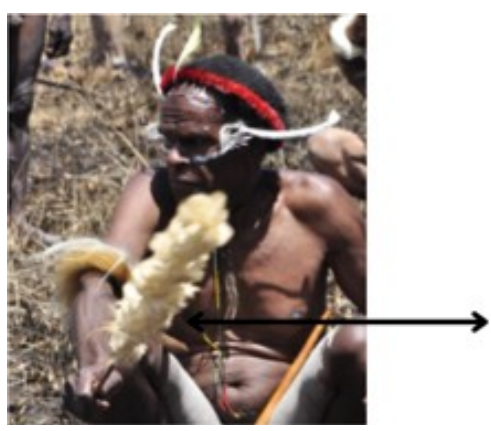

Figure 15. Totok

(source: Department of Culture and Tourism of Brawijaya Regency)

Tabel 2. Attributes of Armaments

\begin{tabular}{|c|c|c|c|c|}
\hline No & Image & Name & Ingredient & Funsion \\
\hline 1 & & $\begin{array}{l}\text { Spear or } \\
\text { Sage } \\
\text { Haliken }\end{array}$ & $\begin{array}{l}\text { Iron wood (joli), } \\
\text { sharpened } \\
\text { animal bone are } \\
\text { poisoned }\end{array}$ & $\begin{array}{l}\text { Weapons of war } \\
\text { and hunting. } \\
\text { Black sage joli is } \\
\text { made of iron wood } \\
\text { (joli) and white Lugu } \\
\text { sage is made of } \\
\text { white iron wood } \\
\text { (lugu). }\end{array}$ \\
\hline 2 & & $\begin{array}{l}\text { Arrow or } \\
\text { Jubi }\end{array}$ & Ironwood & $\begin{array}{l}\text { Weapons of war } \\
\text { and hunting. } \\
\text { The black arrow is } \\
\text { named sike } \\
\text { ewesike, the white } \\
\text { arrow is named sike } \\
\text { wolokonsike and the } \\
\text { white arrow is } \\
\text { named sike } \\
\text { harmaman }\end{array}$ \\
\hline 3 & (2) & $\begin{array}{l}\text { Srick or } \\
\text { Totok }\end{array}$ & $\begin{array}{l}\text { Hite or fite } \\
\text { wood, bird } \\
\text { feathers and } \\
\text { jolalek rope }\end{array}$ & $\begin{array}{l}\text { Instruments of War } \\
\text { and Complementary } \\
\text { dance. This tool } \\
\text { serves to deflect } \\
\text { arrows }\end{array}$ \\
\hline
\end{tabular}


Tradition in the habits inherited by the ancestors of the ancestors in the form of storing objects as evidence of the victory or defeat of the war "ap warek or sue warkek", is used as a tool of worship and is sacred. These objects will be stored properly and maintained in the Customs of War [15]. The tradition of storing winning objects is one of the causes of tribal wars. The objects stored in the Honai Customary War can be told to the next generation so that the next generation knows the enemy and their sibling's lineage. As a supporter of customs, it also reflects that the Hubula Tribe has made Honai like a museum. The way of storing war equipment and attributes is done conventionally by smearing pork oil before storing it. This can be seen how the Hubula Tribe maintains and cares for attribute equipment and jewelry with materials that are around them. Although the ancestors of the Hubula Tribe did not have high technological skills, they were able to make jewelry, not only as a complement but also as an attribute of war and hunting. It opens our eyes that Indonesia has cultural elements that are diverse and need to be preserved from generation to generation.

\section{CONCLUSION}

Traditional clothing is a costume give a tribe certain characteristics that are used as ethnic and regional identities as every ethnic group has different customs and has its own uniqueness. After the overall contents of the attributes of the war costumes of the Hubula tribe in the Baliem Valley, the researcher concludes that there is a relevance between clothing and the attributes of the war of the Hubula tribe. This relevance can be seen from the culture of war between tribes in the Hubula community in the Baliem Valley. War is one of the cultures in the Hubula Tribe, they always solve every problem through war. The Hubula Tribe made war attributes using natural materials that were around them. The abut used to complete the war and protect themselves. Tools of war can also be used for survival as well. The Hubula although they have no pleasure in technology they have mastered how to preserve the attributes of war by using natural ingredients such as lard and leaf shoots. Objects that proved victory became the basis of the history of the tribal war. On the basis of these objects make Honai like their tribal museum. Futher research is needed in order to find out the ins and outs of the origins of way the attribute designs of war costume and jewelry of the Hubula
Tribe can be created where these items can be cultivated both in from and by way of making.

\section{REFERENCES}

[1] Alua, Agus A, et al., Nilai-Nilai Hidup Masyarakat Hubula di Lembah Baliem Papua, STFT Fajar Timur Jayapura, 2006.

[2] Bahari, Hamid, Kitab Budaya Nusantara, Diva Press, Yogyakarta, 2011.

[3] Banoe, Pono, Kamus Musik, Kanisius, Yogyakarta, 2011.

[4] Depdikbud, Kamus Umum Bahasa Indonesia, Balai Pustaka, Jakarta, 1988.

[5] Husni, Muhammad Drs, \& Siregar, Rita Tiarma Dra., Perhiasan Tradisional Indonesia : Direktorial Permuseuman Direktoral Jendaral Kebudayaan, 2000.

[6] Koentjaraningrat, Beberapa Pokok Antropologi Sosial, Dian Rakyat, Jakarta, 1985.

[7] Koentjaraningrat, Pengantar Ilmu Antropologi, Rineka Cipta, Jakarta, 1990. Peraturan Bersama Menteri Dalam Negeri Dan Menteri Kebudayaan Dan Pariwisata Nomor 42 Tahun 2009/Nomor 40 Tahun 2009 Tentang Pedoman Pelestarian Kebudayaan

[9] Permanasari, Arlina dkk, Pengantar Hukum Humaniter, International Commite Of The Red Cross,Jakarta, 1999.

[10] Poesponegoro, M. D. dan Nugroho Notosusanto, Sejarah Nasional Indonesia, Balai Pustaka,Jakarta, 1993.

[11] Tabrani, Primadi. Dr. Prof., Bahasa Rupa, Kelir, Bandung, 2012.

[12] Susan, Novri, Sosiologi konflik teoriteori dan analisis, Prendamedia group, Jakarta, 2009.

[13] Soejono, R. P. dan R. Z. Leirissa, Sejarah Nasional Indonesia, Balai Pustaka, Jakarta, 2007.

[14] Wetipo,Alpius Drs., Megenal Seni dan Budaya Orang Balim. Papua : Dinas Kebudayaan dan Pariwisata Kebupaten Jayawijaya, 2019.

[15] Wetipo,Alpius Drs., Suku HubulaBudaya Perang Suku Masa Lalu : Dinas Kebudayaan dan Pariwisata Kebupaten Jayawijaya, 2018 